\title{
Genetics and epidemiology may contribute to understanding the pathogenesis of IBD - a new approach is now indicated
}

\author{
A Salvador Peña, MD, PhD, J Bart A Crusius, Biol Scl, Marco Oudkerk Pool. MD, \\ Mercedes Gracla Casanova, MD, PhD, Gerard Pals, PhD, \\ Stephan GM Meuwissen, MD, PhD, Marius J Giphart, PhD
}

\begin{abstract}
AS PEÑA, JBA CRUSIUS, M OUdERK POOL, et al. Genetics and epidemiology may contribute to understanding the pathogenesis of IBD - a new approach is now indicated. Can J Gastroenterol 1993:7(2):71-75. The present article summarizes the genetic and epidemiological factors contributing to the pathogenesis of inflammatory bowel disease (IBD) in which a consensus seems to have been reached. The factors identified so far strongly support the involvement of the immune system in disease predisposition to IBD. The models that have resulted from segregation analysis of families with multiple cases of IBD have led to propose a multifactorial inheritance for Crohn's disease and ulcerative colitis - a recessive gene in Crohn's disease and a dominant gene for ulcerative colitis. At present, the lack of genetic markers does not allow the acceptance of any one of these models. Some environmental factors, such as perinatal infections, absence of breastfeeding, smoking in Crohn's disease, influence of transfusion in diminishing relapses in Crohn's disease and drugs that are active in controlling these diseases, may imply the existence of an abnormal immunoregulation in the control of inflammation. New technology is available to approach the problem.
\end{abstract}

Key Words: Crohn's disease, Epidemiology, Genetics, Human leucocyte antigens, Immunogenetics, Inflammatory bowel disease, Tumour necrosis factor, Ulcerative colitis

\section{Considérations génétiques et épidémiologiques dans la compréhension de la pathogenèse de la maladie intestinale inflammatoire: indications d'une nouvelle approche}

RÉSUMÉ: Le présent article résume les facteurs génétiques et épidémiologiques qui contribuent à la pathogenèse de la maladie intestinale inflammatoire au sujet desquels un consensus semble avoir été atteint. Les facteurs identifiés jusqu'à présent appuient nettement le rôle du système immunitaire dans la prédisposition

Department of Gastroenterology and the Institute of Human Genetics, Free University Amsterdam, Department of Immunohematology, University of Leiden, The Netherlands and Department of Paediatrics, University of Zaragoza, Zaragoza, Spain

Correspondence and reprints: Dr AS Peña, Free University Hospital, Department of

Gastroenterology, PO Box 7057, 1007 MB Amsterdam, The Netherlands
卫 ${ }_{\text {ence the IS OVERWHELMING EVID- }}$ role in causing inflammatory bowel disease (IBD) (1-5). The observations supporting hereditary factors are increased familial incidence, higher prevalence of the disease in monozygotic versus dizygotic twins, higher rates in first degree relatives versus spouses and varied frequency found in different ethnic groups (Table 1). Since IBD has a variable age of onset, usually starting after 10 years of age, risks are dependent on the age-specific incidence; these have been calculated for patients in Baltimore, Maryland, USA (6) and for the Ashkenazi Jewish population from Los Angeles, California (7). This Jewish population has a three to four times higher risk of developing IBD than their non-Jewish neighbours. Ashkenazi Jews of middle European origin have an excess risk in relation to Jews of Polish/Russian origin $(8,9)$.

The association of IBD with diseases of known genetic predisposition also supports the genetic predisposition. The diseases associated with IBD (such as ankylosing spondylitis, psoriasis, atopy and eczema, celiac disease, multiple sclerosis, autoimmune hemolytic anemia and primary sclerosing cholangitis) are linked to genes of the major histocompatibility complex (MHC). 
à cette maladie. Les modèles qui ont résulté de l'analyse des familles où se présentaient plusieurs cas de maladie intestinale inflammatoire ont permis de formuler une hypothèse multi-factorielle héréditaire de la maladie de Crohn et de la colite ulcéreuse, soit un gène récessif dans la maladie de Crohn et un gène dominant dans la colite ulcéreuse. À l'heure actuelle, le manque de marqueurs génétiques ne permet pas de confirmer l'un ou l'autre de ces modèles. Certains facteurs environnementaux, comme les infections péri-natales, l'absence d'allaitement maternel, le tabagisme dans la maladie de Crohn, l'influence des transfusions sur la diminution des rechutes de la maladie de Crohn et les médicaments actifs dans la maitrise de ces maladies, peuvent permettre de supposer l'existence d'une immuno-régulation anormale dans le contrôle de l'inflammation. Une nouvelle technologie est disponible pour aborder le problème.

Some of these diseases are associated with class I antigens. For example, ankylosing spondylitis is associated with human lymphocyte antigen (HLA)-B27 and HLA-Bw60 (10). Recent studies from Germany showed a special type of genetic heterogeneity of patients with both ankylosing spondylitis and Crohn's disease. The phenotype HLA-B27, -B44 was markedly increased when both diseases coincided. Individuals with this phenotype have a relative risk of 68.8 for the concurrent manifestation of Crohn's disease and ankylosing spondylitis (11, 12). Other diseases found in association with IBD are linked to HLA class II antigens. Celiac disease primarily is associated with the HLA-DQAI*0501 and HLA-DQB1*0201 $(13,14)$. These observations suggest that genes at the short arm of chromosome 6 are also of importance in the disease susceptibility to IBD.

Although in some families ulcerative colitis and Crohn's disease coexist, there is strong disease concordance among family members. In the majority of the studies reported so far (1-5), the familial prevalence of Crohn's disease and ulcerative colitis is higher when the propositus has Crohn's disease. However, a recent study in Italy (15) found no significant differences; the prevalence of ulcerative colitis in first degree relatives of patients with this disease is seven per 1000 and the prevalence of Crohn's disease among first degree relatives of Crohn's disease patients is five per 1000 (15).

The observations of multiple cases in families of patients with IBD have led to the postulation of different forms of segregation (3). Several models have resulted from these analyses. Some investigators propose multifactorial inheritance for Crohn's disease and ulcerative colitis, while others have put forward that segregation analysis of data in families of patients with Crohn's disease supports a recessive gene in Crohn's disease and a dominant gene for ulcerative colitis. No genetic markers exist to test the validity of these models. The numbers of pedigrees with multiple cases collected by any centre are not large enough to permit a valid statistical analysis. Drs G Hellers and L Iselius, from the Huddinge University Hospital, Huddinge, Sweden, are collecting pedigrees of families with at least two cases of Crohn's disease or ulcerative colitis to perform complex segregation analysis.

\section{EPIDEMIOLOGICAL STUDIES}

The different epidemiological factors which may be relevant in disease susceptibility to Crohn's disease and ulcerative colitis are shown in Table 2 (16-18). There are many studies showing that the relative risk of ulcerative colitis developing in nonsmokers definitely is higher compared with smokers (ex-smokers usually develop their disease after stopping smoking). Epidemiological studies (19-22) consistently support a different association of cigarette smoking with ulcerative colitis and Crohn's disease. It has been suggested that in genetically predisposed individuals, smoking exposure may determine the type of IBD that will develop. A study of identical twins in Sweden showed that the smoking pattern was similar in concordant and dis-

\section{TABLE 1 \\ Observations supporting a genetic predisposition to IBD}

- Increased familial aggregations

- Higher concordance rate in identical twins

- If both parents are affected, higher prevalence in children

- Low prevalence in spouses

- Increased prevalence in some ethnic groups

- Association to diseases with known genetic predisposition

TABLE 2

Environmental factors in IBD

- Perinatal infections

- Lack of breast feeding or early weening

- Higher urban prevalence

- Low socioeconomic status

- Smoking

- Use of oral contraceptives

- Viral and bacterial infections

- Increased incidence over too short a time span

cordant twins; after diagnosis two healthy monozygotic twins had given up smoking during a mean period of 6.5 years without developing ulcerative colitis, implying that the sharing of identical genes and smoking patterns are not enough to develop IBD and indicating that other environmental factors are important (23).

Heavy smoking produces a reduced ratio of $T$ helper-inducer to $T$ suppressor cells (24). There is also some evidence that smoking increases production of colonic mucus in vitro (25). Prytz et al (26) have shown that intestinal permeability is decreased as measured by the oral tracer ${ }^{51} \mathrm{Cr}$ EDTA in patients who smoke and have ulcerative colitis. This protective effect of smoking seems to be due to nicotine. Srivastava et al (27) have shown that 15 or $30 \mathrm{mg}$ of nicotine administered transdermally for four weeks to patients suffering from mild ulcerative colitis produced a significant improvement ( 10 of 16 patients treated improved histologically). In Crohn's disease, vascular abnormalities are more severe 
than in ulcerative colitis (28). The prothrombotic effects of smoking predominate since it is well known that smoking induces endothelial cell damage (29). Smoking could worsen the ischemic process. The thrombogenic vasoconstrictive effects would explain the higher susceptibility to tobacco in women using oral contraceptives $(30,31)$. The risk of developing IBD in oral contraceptive users may be increased for Crohn's disease but not for ulcerative colitis (this issue, however, has not been settled).

The environmental factors identified so far, such as dietary factors, smoking patterns and the use of oral contraceptives, appear to be more important as risk factors for developing Crohn's disease than for ulcerative colitis.

Some of the environmental factors found in epidemiological studies, eg, increased perinatal infections in a cohort of patients with IBD, lack of breastfeeding and influence of blood transfusion (the number of relapses in Crohn's disease diminishes after blood transfusion [32]), may imply the existence of an abnormal immunoregulation in the control of inflammation. The kind of drugs active in controlling these diseases supports this idea.

\section{THE IMMUNE SYSTEM, THE ENVIRONMENT AND IBD}

In the interaction between genes and the environment, the ultimate defence mechanisms to eliminate pathogens, infected or malignant cells, is generation of a specific immune response. The immune system of the gastrointestinal tract consists of a complex network which has to distinguish between foreign proteins (the majority of which are beneficial to the organism) and the toxic proteins which have to be eliminated. To deal with these special environmental conditions, the gut has developed a specific way to recognize foreign proteins without mounting an immune response (tolerance) or producing secretory immunoglobulin $\mathrm{A}$, which is not able to activate complement. T cells in the gut do not respond by proliferating but rather by producing a variety of cytokines. Many genes are involved in the development of specific immune function. A set of closely linked genes at the short arm of chromosome 6 plays a unique role in regulating the immune system: HLA classes I and II are involved in immune recognition; CD4. positive $T$ lymphocytes recognize antigens processed by the antigen presenting cells (eg, macrophages) and these are presented together with Class Il molecules, resulting in proliferation and lymphokine production; CD8positive T lymphocytes recognize peptides presented by class I molecules, resulting in killing of the target cell; and the region between class I and class II genes, the 'central region', encodes at least 20 genes whose macrophage products regulate $\mathrm{B}$ cell proliferation and antibody production $(33,34)$. Several characteristics of the genes responsible for regulation of the immune response may explain the epidemiology of IBD. The polymorphism of the HLA system, ie, the occurrence of different alleles in each locus of the $\mathrm{MHC}$, evolves through natural selection. It is believed that certain MHC alleles have provided protection of the species during evolution by protecting against fatal infections during childhood. These MHC alleles are transmitted from generation to generation. Evidence to support this suggestion comes from data obtained in Marek's disease of chickens (35), in Dutch survivors of typhoid and yellow fever epidemics in Surinam (36), and in malaria in west Africa. HLA-Bw53 and DRB1*1302 diminish the risk of severe malaria (37). In the latter, tumour necrosis factor (TNF) may be involved in selection of people with diminished risk to autoimmune disease (38). IBD is less frequent in areas where autoimmune disease is unusual. The immune system at birth is immature; immunity in the baby is partly obtained through breastfeeding, and perinatal infections may therefore play a role in the predisposition to IBD by exerting its effects when the immune system is not fully developed, probably by interfering with the normal mechanisms of tolerance. The immune system also is influenced by emotional factors, per-

\section{TABLE 3 \\ Working hypothesis to understand the interaction between genetic predisposition and environmental factors in IBD}

- A specific combination of genes on chromosome 6

- Immune system under stress due to abnormal mucus composition. abnormal permeability

- Defect in control of inflammation. dysregulated cytokine production (other genes may be involved)

- In ulcerative colitis autoimmunity predominates, while in Crohn's disease defect in control of inflammation predominates

\section{TABLE 4 \\ Approach to the study of the genetic predisposition in IBD}

\section{Select patient subgroup}

Immunological marker

- Neutrophil antibodies (pANCA) in a subset of patients with ulcerative colitis

- Antibodies to Mr 40,000 epithelial cell antigen in ulcerative colitis

Proposed gene markers to be studied

- HLA (class I and II), central region of the HLA system

- Complementhaplotypes

- T cell receptor genes

Indirect markers

- Intestinal permeability

- Mucus glycoproteins

HLA Human leukocyte antigen: Mr Molecular weight

haps through neuropeptides and other hormones.

\section{REGULATION OF GENE EXPRESSION}

Gene transcription in the cells of the immune system can be induced by viral infections, heat shock and hormones. Many of these external and internal factors lead to the binding of positive regulatory molecules to specific sequences in the enhancer and promoter segments. For example, interferon (IFN) $-\gamma$ and TNF induce class II expression. The regulatory molecules interact with DNA and activate the RNA polymerase, resulting in augmentation of RNA synthesis (34). 


\section{A MOLECULAR STUDY OF GENES FOR TNF IN IBD}

TNF $\alpha$ (cachectin) and $\beta$ (lymphotoxin) are cytokines secreted by activated macrophages, T cells, B cells and natural killer cells (TNF $\alpha$ ), and mitogen-stimulated lymphocytes (TNF $\beta)(39,40)$. TNF $\alpha$ plays a role in the acute-phase response to inflammation and induces an increase of $\mathrm{MHC}$ class Il expression in vitro (41). Human $T$ lymphocytes isolated from the lamina propria of colonic specimens triggered by anti-CD3 produce TNF $\alpha$ and IFN $\gamma$, which are able to kill cells from human colonic epithelial cell lines (42). These cytokines, therefore, may be important in the immune reactions observed in patients with IBD.

As mentioned above, the human MHC carries the genes for TNF $\alpha$ and $\beta$ (43). Polymorphism in the TNF $\alpha$ gene has been detected in the New Zealand White mouse strain and appears to be implicated in the susceptibility of (New Zealand Black x New Zealand White) Fl hybrid mice to lupus nephritis. In humans, HLA-DR2 individuals produce less TNF $\alpha$ than individuals who are HLA-DR3 and HLA-DR4 $(44,45)$.

TNF may contribute to the susceptibility of IBD. In a preliminary study of the bi-alielic TNF $\beta$ Ncol polymor-

\section{REFERENCES}

1. Podolsky DK. Inflammatory bowel disease (First of two parts). N Engl J Med 1991;325:928-37.

2. Orholm M, Munkholm P, Langholz E, Nielsen OH, Sørensen TIA, Binder V. Familial occurrence of inflammatory bowel disease. N Engl J Med 1991;324:84-88.

3. Peña AS. Genetic aspects. In: Järnerot G, Lennard-Jones ], Truelove S, eds. Inflammatory Bowel Diseases. Lancaster MTP Press, 1992: 37-49.

4. Monsén U, Broström O, Nordenvall B, Sörstad J, Hellers G. Prevalence of inflammatory bowel disease among relatives of patients with ulcerative colitis. Scand J Gastroenterol 1987;22:214-8.

5. Monsén U, Bernell O, Johansson C, Hellers G. Prevalence of inflammatory bowel disease among relatives of patients with Crohn's disease. In: Inflammatory Bowel Disease. An Epidemiological and Genetic Study. Thesis Karolinska Institute, Stockholm, Sweden, 1990. phism in 22 Dutch patients with ulcerative colitis, no major deviation of phenotypes was found when compared with the normal population (unpublished results). Further studies using microsatellite polymorphism will be carried out. TNF alleles in combination with high risk HLA-DR-DQ alleles may contribute to heighten the inflammatory reaction. On the other hand, an insufficient production of TNF may be a risk factor for the development of malignancy. The recent association found between HLA-DR2 and ulcerative colitis and HLA-DQB1 in Crohn's disease may suggest that the presence of different alleles in other genes of the Class II region or the central region at the short arm of chromosome 6 may determine whether a patient will develop ulcerative colitis (46-48).

The research on HLA antigens, complement system, TNF and T cell receptor genes is at present in an exciting phase. With rapidly developing new technology the search for genetic markers in IBD has reached a new dimension. The possibility to study with new technology two unlinked loci will enhance understanding of the way the immune system fails to modulate or wrongly directs the gastrointestinal tract defence system. A combination of

6. Calkins BM, Lilienfield AM, Garland CF, Mendeloff AI. Trends in incidence rates of ulcerative colitis and Crohn's disease. Dig Dis Sci 1984;29:913-20.

7. Roth M-P, Petersen GM, McElree C, Vadheim CM, Panish JF, Rotter JI. Familial empiric risk estimates of inflammatory bowel disease in Ashkenazi Jews. Gastroenterology 1989;96:1016-20.

8. Roth M-P, Petersen GM, McElree C, Feldman E, Rotter JI. Geographic origins of Jewish patients with inflammatory bowel disease. Gastroenterology 1989;97:900-4.

9. Zlotogora J, Zimmerman J, Rachmilewitz D. Crohn's disease in Ashkenazi Jews. Gastroenterology 1990;99:286-7.

10. Woodrow JC, Eastwood CJ. HLA-B27 and the genetics of ankylosing spondylitis. Ann Rheum Dis 1978;37:504.9.

11. Purrmann J, Zeidler $\mathrm{H}$, Bertrams J, et al. HLA antigens in ankylosing spondylitis associated with Crohn's genes within the $\mathrm{MHC}$ may predispose the individual to suffer from IBD (Table 3 ). These are early days in this research and the possibility exists that other (clusters of) genes which regulate production of immunoglobulin, encode TNF-receptor(s), adhesion molecules, integrins and addressins in other parts of the human genome may turn out to be of interest in disease predisposition.

\section{FUTURE STUDIES}

A systematic study of the genes which regulate the immune response is indicated. The latest developments in genetics, like the possibility of typing sequence-specific oligonucleotides with the HLA and closely related genes, will undoubtfully help to discover the genes responsible for disease predisposition. However, since clinical features and location of disease at presentation together with the presence of specific complications and evolution of the disease give evidence for the existence of clinical subgroups in patients with IBD, a good integration should exist between the clinicians responsible for managing the patients and the basic scientists in order to select appropriate homogeneous groups (49) (Table 4).

disease. Increased frequency of the HLA phenotype B27, B44. J

Rheumatol 1988;15:1658-61.

12. Mayberry JF, Smart HL, Toghill PJ.

Familial association between coeliac disease and ulcerative colitis. J Roy Soc Med 1986;79:204-5.

13. Sollid LM, Markussen G, Ek J, Gjerde $\mathrm{H}$, Vartdal F, Thorsby E. Evidence for a primary association of celiac disease to a particular HLA-DQ $\alpha / \beta$

heterodimer. J Exp Med 1989;169:345-50.

14. Congia M, Frau F, Lampis R, et al. A high frequency of the A 30, B18, DR3, DRw52, DQw2 extended haplotype in Sardinian celiac disease patients: Further evidence that disease susceptibility is conferred by DQ $\mathrm{A1} * 501, \mathrm{B1} * 0201$. Tissue Antigens 1992:39:78-83.

15. Meucci G, Vecchi M, Torgano G, et al. Familial aggregation of inflammatory bowel disease in northern ltaly: A multicenter study. Gastroenterology 1992;103:514-9.

16. Monk M, Mendeloff AI, Siegel CI, 
Lilienfeld AM. An epidemiological study of ulcerative colitis and regional enteritis among adults in Baltimore. II. Social and demographic factors. Gastroenterology 1969;56:847-57.

17. Wright JP, Frogatti J, O'Keefe EA, et al. The epidemiology of inflammatory bowel disease in Cape Town 1980-1984. S Afr Med J 1986;70:10-5.

18. Odes HS, Fraser D, Krawiec J. Inflammatory bowel disease in migrant and native Jewish populations of southern Israel. Scand J Gastroenterol 1989;24(Suppl170):36-8.

19. Smith MB, Lashner BA, Hanauer SB. Smoking and inflammatory bowel disease in families. Am J Gastroenterol 1988;83:407-9.

20. Katschinski B, Logan RFA, Edmond M, Langman MJS. Smoking and sugar intake are separate but interactive risk factors in Crohn's disease. Gut 1988;29:1202-6.

21. Boyko EJ, Perera DR, Koepsell TD, Keane EM, Inui TS. Effects of cigarette smoking on the clinical course of ulcerative colitis. Scand J Gastroenterol 1988;23:1147-52.

22. Tobin MV, Logan RFA, Langman MJS, McConnell RB, Gilmore IT. Cigarette smoking and inflammatory bowel disease. Gastroenterology 1987;93:316-21.

23. Tysk C, Lindberg E, Järnerot $G$, Floderús-Myrhed B. Ulcerative colitis and Crohn's disease in an unselected population of monozygotic and dizygotic twins. A study of heritability and the influence of smoking. Gut 1988;29:990-6.

24. Miller LG, Goldstein G, Murphy M, Ginns LC. Reversible alterations in immunoregulatory T cells in smoking. Analysis by monoclonal antibodies and flow cytometry. Chest 1982;82:526-9.

25. Cope GF, Heatley RV, Kelleher J. Smoking and colonic mucus in ulcerative colitis. $\mathrm{Br}$ Med J 1986;293:481.

26. Prytz H, Benoni C, Tagesson C. Does smoking tighten the gut? Scand ] Gastroenterol 1989;24:1084-8.

27. Srivastava ED, Russell MAH, Feyerabend C, Williams GT, Masterson JG, Rhodes J. Transdermal nicotine in active ulcerative colitis. Eur J Gastroenterol Hepatol 1991;3:815-8.
28. Wakefield AJ, Sankey EA, Dhillon AP, et al. Granulomatous vasculitis in Crohn's disease. Gastroenterology 1991;100:1279-87.

29. Jeremy JY, Mikhailides DP. Smoking and vascular prostanoids: Relevance to the pathogenesis of atheroma and thrombosis. J Smoking-related Dis 1990;1:59-69.

30. Calkins BM, Mendeloff AI, Garland C. Inflammatory bowel disease in oral contraceptive users. Gastroenterology 1986;91:523-4. (Lett)

31. Vessey M, Jewell D, Smith A, Yeates D, McPherson K. Chronic inflammatory bowel disease, cigarette smoking, and use of oral contraceptives: Findings in a large cohort study of women of childbearing age. Br Med J 1986;292:1101-3.

32. Peters WR, Fry RD, Fieshman JW, Kodner IJ. Multiple blood transfusions reduce the recurrence rate of Crohn's disease. Dis Colon Rectum 1989;32:749-53.

33. French $\mathrm{MAH}$, Dawkins RL, Central MHC genes, IgA deficiency and autoimmune disease. Immunology Today 1990;11:271-4.

34. Giphart MJ, van der Poel JJ. Molecular biology of the HLA system and its relevance for immunohaematology. Baillière's Clinical Haematology 1991;4:975-1010.

35. Briles WE, Stone HA, Cole RK. Marek's disease: Effects of B histocompatibility alloalleles in resistant and susceptible chicken lines. Science 1977;195:193-5.

36. de Vries RR, Khan PM, Bernini LF, van Loghem E, van Rood JJ. Genetic control of survival in epidemics. J Immunogen 1979;6:271-7.

37. Hill AVS, Allsopp CEM, Kwiatkowski D, et al. Common West African HLA antigens are associated with protection from severe malaria. Nature (London) 1991;352:595-600.

38. Butcher GA. Does malaria select for predisposition to autoimmune disease? J Roy Soc Med 1991;84:451-2. (Edit)

39. Gray PW, Aggarwal BB, Benton CV, et al. Cloning and expression of cDNA for human lymphotoxin, a lymphokine with tumour necrosis activity. Nature (London) 1984;312:721-4.

40. Pennica D, Nedwin GE, Hayflick JS, et al. Human tumour necrosis factor:
Precursor structure, expression and homology to lymphotoxin. Nature (London) 1984:312:724-9.

41. McDonald GB, Jewell DP. Class II antigen (HLA-DR) expression by intestinal epithelial cells in inflammatory diseases of the colon. J Clin Pathol 1987;40:312-5.

42. Deem RL, Shanahan F, Targan SR. Triggered human mucosal T cells release tumour necrosis factoralpha and interferon-gamma which kill human colonic epithelial cells. Clin Exp Immunol 1991;83:79-84

43. Spies T, Morton CC, Nedospasov SA, Fiers W, Pious D, Strominger JL. Genes for the tumor necrosis factors alpha and beta are linked to the human major histo- compatibility complex. Proc Natl Acad Sci USA 1986;83:8699-702.

44. Jacob CO, McDevitt HO. Tumour necrosis factor-alpha in murine autoimmune 'lupus' nephritis. Nature (London) 1988;331:356-8.

45. Jacob CO, Fronek Z, Lewis GD, Koo M, Hansen JA, McDevitt HO. Heritable major histocompatibility complex class II-associated differences in production of tumor necrosis factor alpha: Relevance to genetic predisposition to systemic lupus erythematosus. Proc Natl Acad Sci USA 1990;87:1233-7.

46. Asakura $\mathrm{H}, \mathrm{T}$ suchiya $\mathrm{M}, \mathrm{A}$ iso $\mathrm{S}$. Association of human lymphocyteDR2 antigen with Japanese ulcerative colitis. Gastroenterology $1982 ; 82: 413-8$

47. Rotter JI, Wang S-J, Yang H, et al. Genetic heterogeneity between ulcerative colitis (UC) and Crohn's disease (CD) identified by molecular HLA class II association. Gastroenterology 1992;102:A688. (Abst)

48. Neigut D, Proujansky R, Trucco M, et al. Association of an HLA-DQB-1 genotype with Crohn's disease in children. Gastroenterology 1992;102:A671. (Abst)

49. Peña AS, Meuwissen SGM. Clinical subgroups in inflammatory bowel disease. In: Targan SR, Shanahan F, eds. Inflammatory Bowel Disease: From Bench to Bedside. Baltimore: Williams and Wilkins. (In press) 


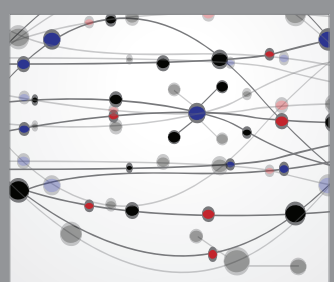

The Scientific World Journal
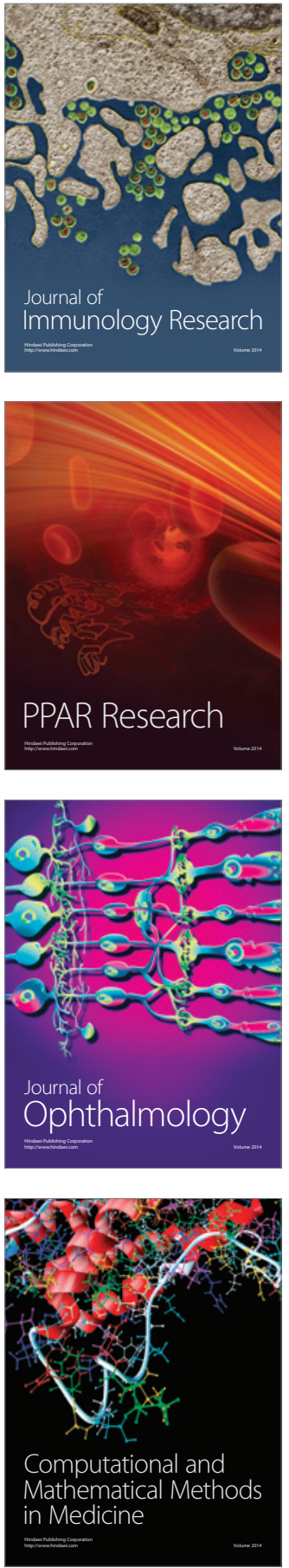

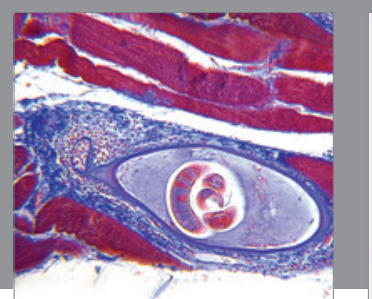

Gastroenterology Research and Practice

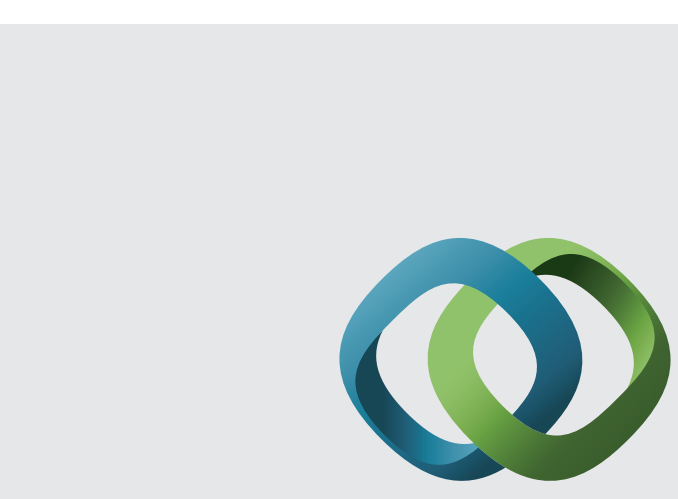

\section{Hindawi}

Submit your manuscripts at

http://www.hindawi.com
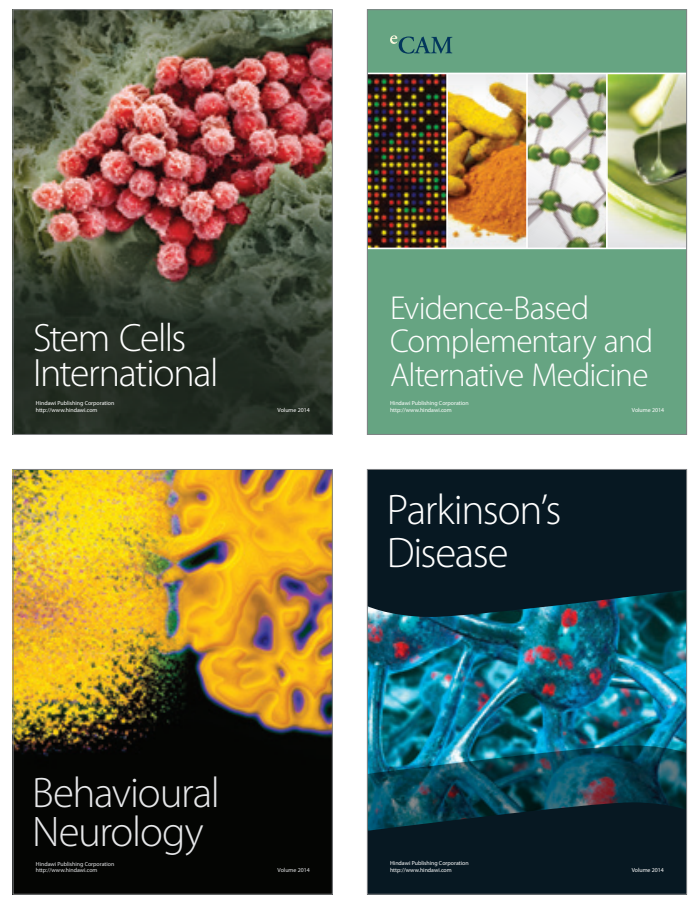
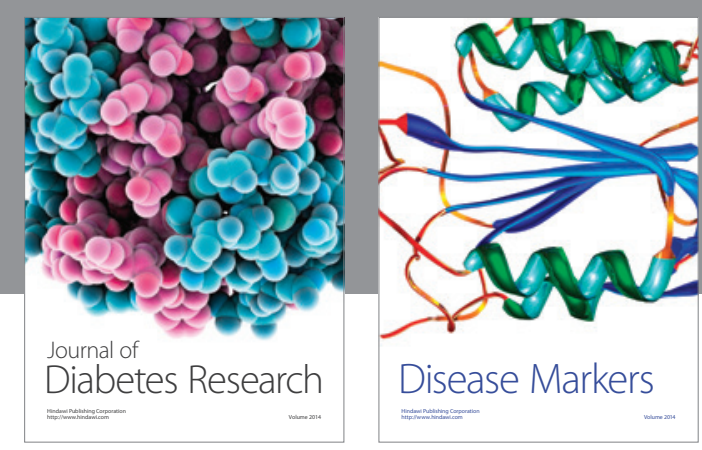

Disease Markers
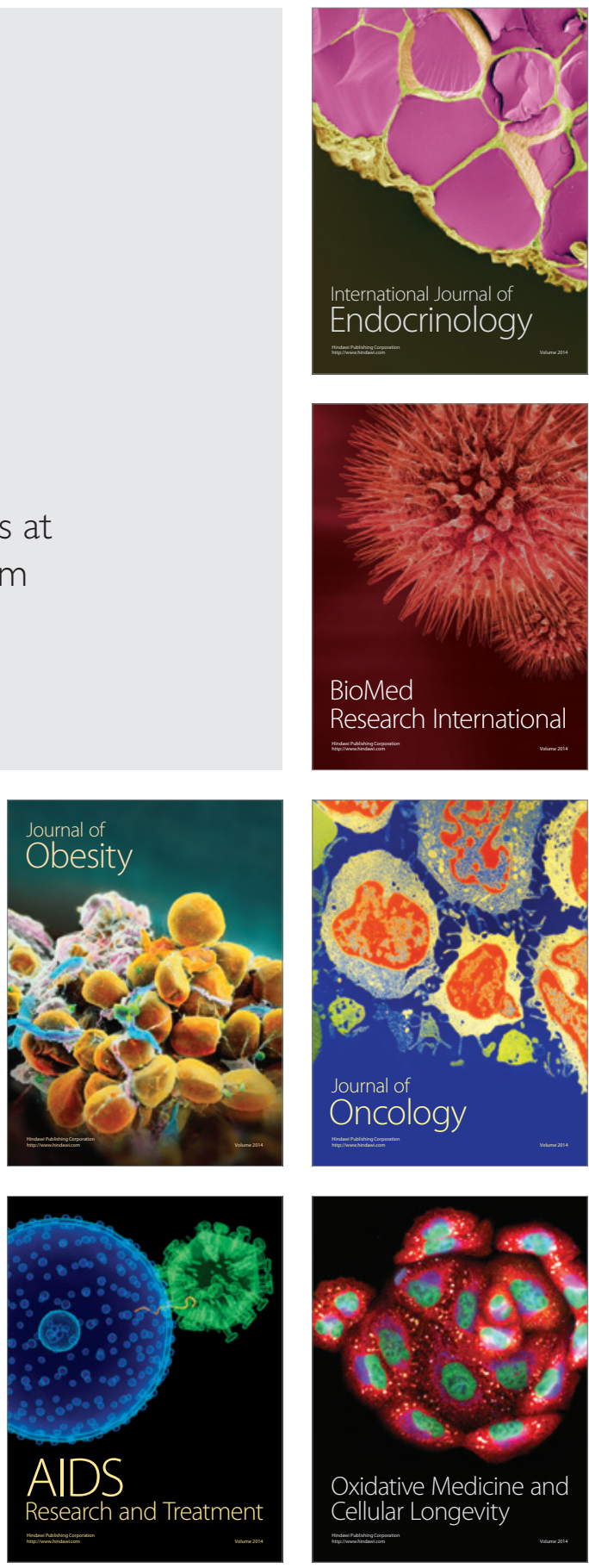